\title{
Correction to: Prevalence and risk factors for lung involvement on low-dose chest CT (LDCT) in a paucisymptomatic population of 247 patients affected by COVID-19
}

Maxime Castelli ${ }^{1+}$, Arnaud Maurin ${ }^{1}$, Axel Bartoli ${ }^{1,2}$, Michael Dassa ${ }^{1}$ (D, Baptiste Marchi ${ }^{1}$, Julie Finance ${ }^{3}$, Jean-Christophe Lagier ${ }^{3,4}$, Matthieu Million, 3,4, Philippe Parola ${ }^{3,5}$, Philippe Brouqui ${ }^{3,4}$, Didier Raoult ${ }^{3,4}$, Sebastien Cortaredona ${ }^{3,5}$, Alexis Jacquier ${ }^{1,2}$, Jean-Yves Gaubert ${ }^{1,6,7}$ and Paul Habert ${ }^{1,6,7^{*}+}$ (C)

\section{Correction to: Insights Imaging (2020) 11:117 https://doi.org/10.1186/s13244-020-00939 $-7$}

The original article [1] mistakenly omitted the Key Points section at the beginning due to an error by the production team that processed the article.

Ahead is the Key Points section as originally intended for presentation in the article:

\section{Key points}

1. In a paucisymptomatic population the prevalence of COVID-19 pneumonia on LDCT was $54 \%$.

2. Age $>54$ years and diabetes were significant risk factors to detect score $\geq 10$ in the multivariate analysis. Rhinitis and anosmia were protector.

3. We reported incidental imaging findings in 47 patients (19\%) and 14 patients $(0.6 \%)$ will require follow-up.

\begin{abstract}
Author details
${ }^{1}$ Radiology Department, La Timone Hospital, Assistance Publique Des Hopitaux de Marseille, 264 Rue Saint Pierre, 13005 Marseille 05, France. ${ }^{2}$ UMR 7339, CNRS, CRMBM-CEMEREM (Centre de Resonance Magnetique Biologique et Medicale - Centre d'Exploration Metaboliques par Resonance Magnetique), Assistance Publique - Hopitaux de Marseille, Aix-Marseille Universite, 13385 Marseille, France. ${ }^{3}$ IHU-Mediterranee Infection, Marseille, France. ${ }^{4}$ IRD, APHM, Aix Marseille Univ, MEPHI, Marseille, France. ${ }^{5}$ IRD, APHM, Aix Marseille Univ, VITROME, Marseille, SSA, France. ${ }^{6}$ LIIE, Aix Marseille Univ, Marseille, France. ${ }^{7}$ CERIMED, Aix Marseille Univ, Marseille, France.
\end{abstract}

Published online: 16 February 2021

\section{Reference}

1. Castelli M, Maurin A, Bartoli A et al (2020) Prevalence and risk factors for lung involvement on low-dose chest CT (LDCT) in a paucisymptomatic population of 247 patients affected by COVID-19. Insights Imaging 11:117. https://doi.org/10.1186/s13244-020-00939-7

\section{Publisher's Note}

Springer Nature remains neutral with regard to jurisdictional claims in published maps and institutional affiliations.

\footnotetext{
*Correspondence: Paul.habert@ap-hm.fr

${ }^{+}$Maxime Castelli and Paul Habert have contributed equally to this work

${ }^{7}$ CERIMED, Aix Marseille Univ, Marseille, France

Full list of author information is available at the end of the article
}

(C) The Author(s) 2021. Open Access This article is licensed under a Creative Commons Attribution 4.0 International License, which permits use, sharing, adaptation, distribution and reproduction in any medium or format, as long as you give appropriate credit to the original author(s) and the source, provide a link to the Creative Commons licence, and indicate if changes were made. The images or other third party material in this article are included in the article's Creative Commons licence, unless indicated otherwise in a credit line to the material. If material is not included in the article's Creative Commons licence and your intended use is not permitted by statutory regulation or exceeds the permitted use, you will need to obtain permission directly from the copyright holder. To view a copy of this licence, visit http://creativecommons.org/licenses/by/4.0/. 